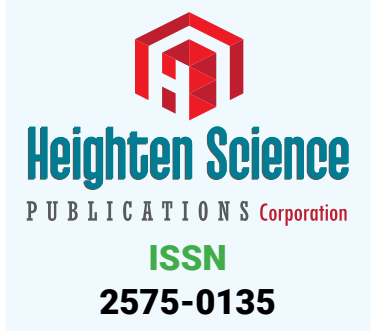

*Address for Correspondence: Ruiz Alvarado Cristina, Institute of Agricultural Sciences of the Autonomous, University of Baja California, México, Email: erueda04@santana.uson.mx

Submitted: 21 May 2018

Approved: 07 June 2018

Published: 08 June 2018

Copyright: @ 2018 Cristina RA, et al. This is an open access article distributed under the Creative Commons Attribution License, which permits unrestricted use, distribution, and reproduction in any medium, provided the original work is properly cited.

Keywords: Bacterial canker; Identification; Diagnosis

Check for updates
Research Article

\section{Detection of Clavibacter}

\section{michiganensis subsp. michiganensis in tomato and chili seeds and farming area of Sinaloa, Mexico}

\author{
Ruiz Alvarado Cristina ${ }^{1 *}$, Soto Ortiz Roberto ${ }^{1}$, Cervantes Diaz \\ Lourdes $^{1}$, Nuñez Ramirez Fidel ${ }^{1}$, Celaya-Michel Hernán ${ }^{2}$ and \\ Rueda Puente Edgar $0^{2}$ \\ 'Institute of Agricultural Sciences of the Autonomous, University of Baja California, México \\ 2University of Sonora, Department of Agriculture and Livestock, Highway Hermosillo-Kino Bay, \\ Mexico
}

\section{Abstract}

Phytosanitary inspectors play an important role in diagnosing diseases in foreign plant material. However, some deficiencies have been detected in the detectionc ausing the entrance of many microorganisms. Therefore, it was of great interest to detect the presence of Clavibacter michiganensis subsp. michiganensis $(\mathrm{Cmm})$ in foreign tomato and chili seed in the agricultural area of Sinaloa, Mexico, besides the growth and cell density of $\mathrm{Cmm}$ was evaluated in different selective media under continuous illumination and photoperiod. The results indicate that seeed of 35 varieties of tomatoes was collected; while for Chili seed were 18 . This study was supported by farmers (225) which represent $79 \%$ of all growers and 32 business engaged in the sale of agrosupplies, provided seeds of varieties and hybrids. Those growers are from six areas (Culiacan, El Tamarindo, Navolato, Culiacan, El dorado and Badiraguato). For detection of $\mathrm{Cmm}$ in tomato seed, from 35, only four was variability considering Immunochromatography and ELISA techniques; however, considering chemical and physiological test, the result was negative. Similar results were in 18 varietes of chili seed, where eight showed variability to detect $\mathrm{Cmm}$, and negative by chemical and physiological test. According to the growth and cell density of $\mathrm{Cmm}$, the optimal medium was YDC under $\mathrm{pH}$ stable and continuous light conditions. It is recommended to consider the fusion of diagnostic techniques in the emission of a result.

\section{Introduction}

In Mexico country, horticulture is one of the most important agricultural activities, for foreign exchange earnings and employment generation. In Mexico, about 512,000 ha of vegetables are planted, which is equivalent to $3.5 \%$ of the national agricultural area and produces a production of eight million tons (ton), which is equivalent to $9.4 \%$ of the production of the sector [1]. Due to the diversity of microclimates and types of soil in Mexico country, favorable yields are obtained in the 49 horticultural species that are cultivated, because is possible to obtain these products throughout the year. Among the main crops listed are potatoes, tomatoes, onions and chili, products with the highest consumption nationwide. From all production of those crops, $43 \%$ is export, while $57 \%$ is for national consumption. The main producing States of crops in Mexico country are Sinaloa, Guanajuato, Sonora, Queretaro, Baja California, Jalisco and Morelos. The state of Sinaloa generates $57 \%$ of the national production established in 80,000 ha with $89 \%$ to the export market [2], which is why it has to produce with excellent quality standards. 
Tomato and chili are the main horticultural species in Mexico country and in the State of Sinaloa. There are of tomato crops: salladette and ball in an area of 30.000 ha. Among the chili crops, appear the bell, jalapeno, serrano, Anaheim, Caribbean and pasilla; however the first two are the main crops since 1987, in an area closed to 3.435 288 ha Velazquez et al., 2008. Nevertheless, among factors limiting the production of these vegetables, there are the diseases caused by fungi, bacteria, phytoplasmas, viruses and nematodes, which cause great economic losses. Phytosanitary problems have increased, partly due to the lack of an accurate diagnosis and timely, which is why farmers have not been able to properly handle the impact of disease [3].

Traditionally, the observation of symptoms for the field technicians or growers, is the strategy to diagnose and treat disease, which is not the most appropriate, because different pathogens can cause diseases with similar symptoms, or it may be due to a combination of a pathogen with an abiotic factor such as toxicity of chemicals or deficiency of certain minerals in the soil, among others. In the context of this issue of disease management requires accurate diagnosis, which is fundamental to the aid of biochemical, microbiological and molecular techniques. Whereas previously described, the crops of tomato (Lycopersicon esculentum) and chili (Capsicum annuum), are the most representative in northwestern Mexico. In Sonora and Baja California States, tomato and chili are vegetables that have been affected by a sporadic disease, mainly with symptoms of cankers. The Plant Protection Departament in Mexico, has registered as of quarantine disease the causal agent of bacterial canker Clavibacter michiganensis subsp. michiganensis ( $\mathrm{Cmm}$ ), due to the negative effects provoked on agricol regions of U.S., for its high capacity for spread through seed, the capacity to infect vascular tissues through wounds, stomata and trichomes, and generating losses up to $85 \%$ of the crop under favorable conditions [4]. It replication capacity of $\mathrm{Cmm}$ has been caused genetic resistance due to the low efficiency of integrated applied [5].

In Mexico, specifically in the state of Baja California, it was detected that $\mathrm{Cmm}$ causing an alarm since 1994. However, in the 2006-2007 crop season, was again identified $\mathrm{Cmm}$ in commercial tomato and Chili crops, causing damage up to $40 \%$ incidence. After, in the agricultural areas of the state of Sonora, was detected in 2008 and 2009, Rectifying that the state of sinaloa remains on alert because this last State, is a nationally representative area in the production of vegetables; in 2015, national domestic production of tomato was $994,737.85 \mathrm{t}$, where the state of Sinaloa participated with a 28\%; according with the national production of chili, was 476,325.56 t [1].

Phytosanitary offices in ports, airports and phytosanitary booths play an important role in diagnosing diseases on imported material. However, certain deficiencies was detected in the identification of quarantine microorganisms, mainly due to the large volumes of plant material entering to the Mexican country [6,7]. Furthermore, agricultural farmers in Sinaloa State, found symptoms similar to bacterial canker (Cmm), which generated controversy among producers about the presence or absence of this disease. To another hand, different culture media for cultivation have been developed to Clavibacter spp. ranging from formulas to enrich the saline's solution, until the use of artificial culture media; the selection of an appropriate chemical medium is the first step and the most important for the success of the bacterial crop. Bacterium require different factors for its growth: the physico-chemical and the nutritional. Among the first, light, temperature, salinity, $\mathrm{pH}, \mathrm{CO}_{2}$ and photoperiod. Within the seconds macronutrients are relevant, which are used to synthesize organic compounds, and the micronutrients used as catalysts López et al., 2009. The photoperiod (time of exposure to light) is another important factor that has an effect on life cycles and metabolic activities of the bacteria both in cultivation and in nature. Under natural conditions, most microorganisms are established in alternating periods of light: darkness, however, in most laboratories of bacteria remains constant lighting in the crops inside, because it favors the cellular division; when they come to use light cycles: dark, it is with in order to simulate the conditions natural or synchronize the crops [8]. 
Due of above mention, it was of great interest to develop this research with the following goal to detect the presence of Clavibacter michiganensis subsp. michiganensis in tomato and chili seeds in the agricole area of Culiacan, Sinaloa, and evaluate the growth and cell density of Clavibacter michiganensis subsp. michiganenesis $(\mathrm{Cmm})$ in different static selective culture media under continuous illumination and photoperiod in vitro was performed.

\section{Materials and Methods}

\section{Experimental site}

This research was conducted in the municipality of Culiacan Sinaloa, Mexico; the study area is located between geographical coordinates: North $25^{\circ} 10^{\prime}$ and to the South $24^{\circ} 00^{\prime}$ of North of Ecuador and 107 $43^{\prime}$ to the West on the meridian and 106 $956^{\prime}$ in meridian West Longitude.

The research was conducted in two stages: a) collect of chili and tomato seeds used by farmers in Sinaloa State to detect $\mathrm{Cmm}$ using the diagnosis techniques: a) Immunochromatography and b) ELISA; b) sowing of $\mathrm{Cmm}$ in different culture media, under continuous lighting and photoperiod $12 \mathrm{~h}$ light: $12 \mathrm{~h}$ dark, to observ the cell density growth of $\mathrm{Cmm}$.

\section{First stage}

Seed Collection and detection of Clavibacter michiganensis subsp. michiganensis (Cmm) by immunochromatography and ELISA technique (linked immunosorbent assay enzymes):

Obtaining materials tomato and chili seeds, was achieved with the cooperation of companies and agricultural farmers in the agricole region; these provided an amount of 100 to 150 seeds for the analysis to detect $\mathrm{Cmm}$. The seeds were labeled and transported in a cooler at $4^{\circ} \mathrm{C} \pm 2$, to the Biotechnology Lab. Then each of the samples were stored and refrigerated at $4^{\circ} \mathrm{C} \pm 2$, for further diagnosis phytosanitary $[7,9]$.

For the process of identification of $\mathrm{Cmm}$, immunochromatographic technique was applied through inmunostrips following the protocol of the identification by Rueda et al. [9]. The inmunostrips of Cmm were obtained by the mega-project (Detection of bacteria of quarantine in theagro-producing areas of northwestern Mexico 12067 key) and Project key US0313002204. This technique consisted in make grinding of 15 seeds of tomato and chili collected in individual form and placed in each bag containing buffer (SEB4) to detect $\mathrm{Cmm}$. The samples were ground completely in the bag using a handle mortar. Then, in each bag was inserted vertically an a inmunostrips with antibody of $\mathrm{Cmm}$ adhered; the submerged inmunostrips were not more than $0.5 \mathrm{~cm}$ in the damper, in order to avoid false positive results. Fit in mention that in inmunostrips appear two lines in order to avoid confusion at the time of carrying out the diagnosis: a negative control at the top and another indicating the result of a positive reaction. Both lines are manifested after dipping inmunostrips for three minutes in the buffer. The reaction must occur maximum at 30 minutes into the test.

According the ELISA test, this technique was carried out considering protocol from Borboa et al. [10], which it is based on the detection of an antigen immobilized on a solid phase using antibodies that directly or indirectly cause a reaction whose product, such as a dye, can be measured spectrophotometrically. According to Borboa et al. [10], the procedure for $\mathrm{Cmm}$ detection by ELISA consisted of the following steps: a) Sensitization of plates. Analyses were performed in triplicate for a reliable diagnosis. First, for each sample was prepared by a mixture of antibody and cover $1 \mathrm{X}$ buffer, this was done in an Eppendorf tube by mixing $2 \mathrm{~L}$ of antibody buffer plus $400 \mathrm{~L}$ of $1 \mathrm{X}$ coverage. Then add 100 microliters of whole antibody - cushion cover to each well of the plate and allowed to refrigeration at $4{ }^{\circ} \mathrm{C}$ in a humid container overnight. Subsequently carried out the first wash of the plate was to develop washing the plate with 1X PBS-Tween (phosphate buffered saline-Tween), this process was carried out five times to the plate 
to leave no residues in wells, then proceeded to dry wells sanitary paper covering them, turning them upside down and shake to style all PSBT and waste. Then the samples were added, first macerated in a mortar sample (seeds) with $1 \mathrm{~mL}$ or volume of extraction buffer required general. Added $100 \mathrm{~L}$ of the ground sample into each well (two wells), was added $100 \mathrm{uL}$ of positive control (antigen) in the positive control well and $100 \mathrm{~L}$ of extraction buffer in the well generally negative control. Plate was placed in moist container and incubated overnight at $4{ }^{\circ} \mathrm{C}$. The second plate washing involved washing the wells five times with $1 \mathrm{X}$ PBST. After washing they were cleaned sanitary paper covering them, turning them upside down to that style all remaining PBST and debris that may have been. After this the wells were observed to verify that they were free of plant tissues or bubbles, if they contained one of two obstacles must repeat wash. Later was added the set of enzymes, by adding $100 \mathrm{uL}$ of enzyme solution - buffer ECL (chemiluminescence enzyme) to each well and incubated the plate in a moist container for two hours at room temperature. The enzyme solution - ECL buffer was prepared in an Eppendorf tube by adding $2.5 \mathrm{~L}$ of the enzyme $+500 \mathrm{~L}$ of ECL buffer $1 \mathrm{X}$. After a third wash was the plate that held $2 \mathrm{~h}$ of incubation, then washed the wells of the plate 5 times with $1 \mathrm{X}$ PBST. After washing the wells were cleaned sanitary paper covering them, turning them upside down to that style all remaining PBST and debris that may have been. After this the wells were observed to verify that they were free of plant tissues or bubbles, if they contained one of two obstacles must repeat wash. Then the solution was added PNP considered to add $100 \mathrm{~L}$ of PNP substrate in each well and the plate was incubated at room temperature humidity of 15 - 45 minutes. After this time the wells were observed to see the results. The positive control should have a bright yellow and the negative should not change color. Wells were observed with the sample to be analyzed, if the wells were yellow and were taken as positive if it changed color were negative. PNP solution was prepared in an Eppendorf tube by adding 500 microliters of PNP buffer $1 X+1$ / 6 PNP tablet, diluted by the tablet in the resuspension buffer. It should be noted that the tablets were not touched or exposed to strong light, as this could infer the result of color.

\section{Second stage}

Evaluation of treatments on growth and cell density of Clavibacter michiganensis subsp. michiganensis $(\mathrm{Cmm})$ :

Cmm bacteria was grown in Petri dishes on the PDA culture medium for a first fitting to the different media for $24 \mathrm{~h}$. Subsequently cultured in $125 \mathrm{~mL}$ Pteri dishes with three different culture media to be evaluated in YDC, NBY and LPGA for seven days. The medium yeast extract-dextrose (YDC) was prepared with $10 \mathrm{~g}$ of yeast extract, $20 \mathrm{~g}$ of dextrose, $20 \mathrm{~g}$ calcium carbonate (fine powder), $15 \mathrm{~g}$ agar and $1 \mathrm{~L}$ of water; the medium of NBY agar in $15 \mathrm{~g}$ consisted in $8 \mathrm{~g}$ of nutrient broth, $2 \mathrm{~g}$ yeast extract, $2 \mathrm{~g}$ potassium monohydrogen phosphate $\left(\mathrm{K}_{2} \mathrm{HPO}_{4}\right), 0.5 \mathrm{~g}$ of potassium dihydrogen phosphate $\left(\mathrm{KH}_{2} \mathrm{PO}_{4}\right), 2.5 \mathrm{~g}$ of glucose and $1 \mathrm{~L}$ of water; while the medium with yeast LPGA - peptone - glucose and agar according to Rodriguez. Each of the media were exposed under two conditions: a) a photoperiod 12h light (3000 lux): 12h darkness and evaluated for seven days; each of the cultures initiated with an inoculum of 50,000 cfu / $\mathrm{mL}$ (colony forming units / $\mathrm{mL}$ ), and b) continuous light (3000 lux) and evaluated for seven days, each of the cultures initiated with an inoculum of 50,000 cfu / mL. The cultures were maintained under controlled temperature conditions at $22^{\circ} \mathrm{C}$., ten replications were generated for each treatment.

\section{Variables monitored every $12 \mathrm{~h}$}

The variables monitored were: 1 . Temperature, it was measured with a conventional mercury thermometer $\left(-10\right.$ to $\left.120^{\circ} \mathrm{C}\right) .2$. $\mathrm{pH}$, it was measured with a portable potentiometer brand $\mathrm{pH}$ tester 1 Easton, previously calibrated with buffers of 7.0 and 10.0. 3. Lighting was measured with a photometer Fisher Scientific 
brand. 4. Quantification of cell density. This technique was performed by direct counting with a hemacytometer of $0.1 \mathrm{~mm}$ in depth in a compound microscope at 10X and samples fixed with $1 \%$ lugol (Gitaitsis et al. 1987). Data from cell concentrations were transformed to obtain the logarithm base two. Growth rates (number of divisions per day) and doubling time were calculated by the formula $m=\left(\log _{2} B_{n}-\log _{2} B_{0}\right) /\left(t_{n}-\right.$ $\mathrm{t}_{\mathrm{o}}$ ). The cumulative growth rate $(\mathrm{M})$ was obtained from all the rates recorded in the experiment (Em) and the maximum rate was the highest $M$ value obtained during the development of crops.

\section{Experimental design and statistical analysis}

In the present study was used a completely randomized design with analysis of variance (ANOVA) of two ways. We used multiple range test of Duncan with a significance level of $\mathrm{P}<0.05$ to examine differences between treatments. The statistical program used for data analysis was the SAS [11].

\section{Results and Discussion}

\section{First stage}

According to obtaining plant material (seed) of tomato and chili from farmers in agricultural land in Sinaloa State, had the support of six areas (Culiacan, El Tamarindo, Navolato, Culiacan, El dorado and Badiraguato) where farmers provided seeds of varieties and hybrids for the detection of Clavibacter michiganensis subsp. michiganensis $(\mathrm{Cmm})$. It should be noted that in this six areas, a total of 32 business engaged in the sale of agro-supplies donated seed of both crops. Meanwhile, the number of growers were 225, representing $79 \%$ of all growers of high and low scale of the region of Culiacan, Sinaloa, according to Osuna [12], the vegetative material collected were 35 varieties of tomatoes, while for Chili were 18.

\section{Detection by immunochromatography}

According to the method described to detect $\mathrm{Cmm}$, results in tomato seed are shown in table 1, while for the chili seeds are indicated in the table 2. It can be seen that of the 35 different materials of tomato, only four of them showed the presence of $\mathrm{Cmm}$ positive, corresponding to E-9 materials, Saladette Determined, H4b and Peto seed Fiero, which represents $12 \%$ of total seeds collected and $93 \%$ of all varieties which are handled in the Sinaloa State. It is noted that the remaining of growers did not provide plant material (seeds) due to the high economic cost to purchase a pound of tomato seed (\$ 5.0153 US Dollars).

For its part, phytopathological diagnosis developed for chili seed, the results by immunochromatographic technique show that of the 18 materials tested, $48 \%$ proved to be positive for the presence of $\mathrm{Cmm}$. These materials correspond to Northern Nunhems, Lugo, 2/Celdo, BN 942326, Prueba, 3/Celda 10, Arco Seed Anaheim and Impatient F1. These analyzes show that the the seed analyzed is a carrier of the bacterial disease known as "bird's eye" [10].

It is important to point that in developing immunochromatographic test, there was variability of response for the presence of $\mathrm{Cmm}$, offered a positive result at different times. This may be due to the concentration of bacteria in a variety, which is reflected in a quick result or slow, according to Agdia [13]. Also, for the purpose of confirming the identification immunochromatographic each positive test $\mathrm{Cmm}$, the maceration of seeds (solutions) of tomato and chili, several additional tests, were include like a sowed of colonies in selective culture media YDC, where after 28h, bacterial colonies composed type cells rod-shaped bacilli that without observing the curved to form aggregates in a "V", the colonies showed variability to measuring 0.4 to 0.6 microns and 0.8 to 1.2 microns. Likewise, the test was forming endospores, which was negative. The cells under microscopic observation showed no mobility. When those colonies were developed 
Table 1: Detection of $\mathrm{Cmm}$ by Immunochromatography and ELISA in tomato seed, used in Culiacan, Sinaloa.

\begin{tabular}{|c|c|c|}
\hline Seed Tomato & Immunochromatography test to $\mathrm{Cmm}$ & ELISA technique to $\mathrm{Cmm}$ \\
\hline 1. WS-Regidor determinado saladette & - & - \\
\hline 2. WS-Don Vicente & - & - \\
\hline 3. WS-Grandella & - & - \\
\hline 4. WS-Grandello & - & - \\
\hline 5. WS-Budapest & - & - \\
\hline 6. WS-28 & - & - \\
\hline 7. WS-38 & - & - \\
\hline 8. WS-49 & - & - \\
\hline 9. WS-2478 indeterminado Roma & - & - \\
\hline 10. WS-2483 indeterminado Roma & - & - \\
\hline 11. WS-2482 indeterminado Roma & - & - \\
\hline 12. WS-1730 determinado Roma & - & - \\
\hline 13. WS-830600987 indeterminado Bola & - & - \\
\hline 14. WS-830402457 indeterminado Bola & - & - \\
\hline 15. WS-830606311 indeterminado Roma & - & - \\
\hline 16. WS-830711607 indeterminado Roma & - & - \\
\hline 17. WS-830606001 indeterminado Roma & - & - \\
\hline 18. WS-830708161 determinado Roma & - & - \\
\hline 19. WS-830708420 determinado Bola & - & - \\
\hline 20. WS- 830602119 determinado Grape & - & - \\
\hline 21. WS-Castella Bola Racimo & - & - \\
\hline 22. WS-Speedella Bola Racimo & - & - \\
\hline 23. WS-Rootstock Monstro & - & - \\
\hline 24. WS-Rootstock 810700030 & - & - \\
\hline 25. WS-Recova determinado Roma & - & - \\
\hline 26.WS- Regidor determinado Roma & - & - \\
\hline 27. E-9 & + & - \\
\hline 28. Rio Fuego 107 & - & - \\
\hline 29. C-8 & - & - \\
\hline 30. Rio Fuego 102 & - & - \\
\hline 31. Saladette Determinado & + & - \\
\hline 32. Fiero $\mathrm{H}_{4} \mathrm{~B}$ & + & - \\
\hline 33. HYPPEL & - & - \\
\hline 34. Peto Seed & + & - \\
\hline 35. Cerro Gordo bola grande & - & - \\
\hline \multicolumn{3}{|c|}{$\begin{array}{l}\text { Cmm }=\text { Clavibacter michiganensis subsp michiganensis } \\
+=C \mathrm{~mm} \text { Present } \\
-=\mathrm{Cmm} \text { Absent } \\
*=\text { variability of results considering chemical and physiological test }\end{array}$} \\
\hline
\end{tabular}

Table 2: Detection of Cmm by Immunochromatography and ELISA in chile seed, used in Culiacan, Sinaloa.

\begin{tabular}{|c|c|c|}
\hline Seed Chili & Immunochromatography test to $\mathrm{Cmm}$ & ELISA technique to $\mathrm{Cmm}$ \\
\hline 1. Nunhems Norteño & $+^{*}$ & - \\
\hline 2. Hibrido Mili & - & - \\
\hline 3. Chiltepin & - & - \\
\hline 4. Habanero & - & - \\
\hline 5. Bell & - & - \\
\hline 6. Fresnillo & - & - \\
\hline 7. Chile ancho San Martin & - & - \\
\hline 8. Chile Habanero & - & - \\
\hline 9. Chile Cascabel & - & - \\
\hline 10. Santa Fe grande & - & - \\
\hline 11. Jalapeño $M$ & - & - \\
\hline 12. Lugo & $+*$ & - \\
\hline 13. $2 /$ Celdo & $+*$ & - \\
\hline 14. BN 942326 & $+*$ & - \\
\hline 15. Prueba & $+*$ & - \\
\hline 16. 3/Celda 10 & $++^{*}$ & 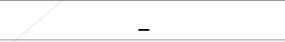 \\
\hline 17. Arco Seed Anaheim & $+*$ & - \\
\hline 18. Impatient F1 & $+*$ & - \\
\hline
\end{tabular}


on YDC, were not generated circular and convex colonies yellow, results that are in disagree with those of Davis et al. [14-16]. It should be noted that the reaction of the immuno response and some physiological evidence of bacterial isolates from tomato seed, i.e. inmobility in bacterial cells, the colonies were yellowish to cream, considering negative results. For this variability of results the test of immunochromatography, was considered as negative.

The Gram staining technique, widely used test because it not only helps determine the shapes of the cells (Cocos, spirilla and bacilli), but also the group of bacteria, was performed in this study, resulting in a negative Gram stain, a finding consistent with Rodriguez [15]. Similarly, physiological tests were applied as catalase obtaining negative results, which helps to differentiate aerobic or anaerobic bacteria; oxidase test was negative, and helps to differentiate enteric bacteria and non-enteric; urease test with a positive results; esculin hydrolysis test was positive; some test results were inconsistent with those cited by Schaad et al. [17-19].

\section{Cmm detection by ELISA}

According laboratory tests to detect Clavibacter michiganensis subsp. michiganensis by ELISA, the enzymatic reveals were evident in tomato and chili seed (Tables 1,2). In table 1 , we can detect some positive results match by Immunochromatography technique for the presence of $\mathrm{Cmm}$. However in comparison with ELISA, this result confirms the importance to consider alternative diagnostic techniques; this variability of results between different diagnostic techniques according to Fatmi and Schaad $[20,21]$, is likely to happen, since factors such as the number of cells, abrasive compounds to the antibody and antigen exposure time to read, light, temperature, etc.., May be conditions to provide a similar result. However, a recommendation to avoid this type of variability [21,22], is the development of repetitions at the time of analysis. This aspect was addressed and confirmed obtaining no presence of $\mathrm{Cmm}$ in tomato seed material of Peto Seed, Fiero $\mathrm{H}_{4}$ B, Saladette Determinado and E-9, by ELISA.

For its part, the results obtained in diagnostic ELISA in chili seeds (Table 2) indicate that only $40 \%$ of the materials is infected with $\mathrm{Cmm}$ by Immunochromatography technique. However, this result compared with the ELISA does not match. In this sense, and according to Lou et al. [21-22], was developed the recommendation to triple analysis, in order to corroborate results, which showed to be negative for the presence of $\mathrm{Cmm}$.

Not with standing the above results, and due the positive results by Immunochromatography technique, is important indicate the possibility how $\mathrm{Cmm}$ can has the ability of bacterial canker spread by seed $[23,24]$. These results show the importance it plays phytopathological diagnosis by health authorities, which should strengthen inspectorates diagnostic measures, and environmental conditions that are manifested in the horticultural zone of Culiacan, is a primary factor in the expression of an epidemic since the state has 1.705 hectares led to the cultivation of tomatoes and chili in a greenhouse, shade house and open pit [1].

Second stage. Evaluation of treatments on growth and cell density of Cmm: Once the Cmm bacteria was grown in culture media YDC, NBY and LPGA, and exposed under two conditions: a) a photoperiod $12 \mathrm{~h}$ light (3000 lux): $12 \mathrm{~h}$ dark to evaluate variables of temperature, $\mathrm{pH}$ and quantification cell density for seven days, the results indicate that at this stage of study, the variable temperature was maintained at $22{ }^{\circ} \mathrm{C} \pm 1.5$ in the different treatments. The $\mathrm{pH}$ ranged from $6.92 \pm 0.36$ to 7.19 \pm 0.34 in the cultures with photoperiod and $6.98 \pm 0.29$ to $7.22 \pm 0.035$ in cultures with continuous light. Nevertheless, the variation observed in this study, according to results obtained by Mansour and Salama [25], is not significant between the two conditions of illumination, prior to that above a unit, the bacterial mortality rates are 
considerable [25], aspect that did not happen in the present study. For its part, the variable bacterial cell growth in culture media, initiated by the adaptation phase where most of the inoculated cells were viable. However, it was observed that binary fission was slow, since they are not immediately able to divide [25]; subsequently observed a continuous exponential growth of the cells, which is indicative of cell division according to Thessen et al. [26]. In this sense, the cell division rate was constant over a period of four days and recorded a maximum growth rate on the fifth day of culture. Then the time required for cell replication decreased, reducing the growth rate, which is a sign of entering the phase of slow growth, this stage occurred between day six and seven was the last day of culture (Figure 1). The growth curves in the three different media and the two light conditions had a similar trend, with growth up until the last days of the experiment and an exponential phase extended mainly to the middle LPGA with photoperiod. In the culture medium YDC was obtained further growth, and to a lesser extent in the medium NBY, while lower values were observed in the the culture medium LPGA. This decrease in growth amid LPGA is because bacteria is adapted to grow with micronutrients near the natural habitat because its vegetable origin, so that the reduction of salts causes there is an increase in cell volume by accumulation of water inside and diversion of their metabolic activities [25] (Figure 1). Analyses of variance indicate that the culture media had a significant effect $(\mathrm{P}<0.05)$ on growth rate and maximum cell density of $\mathrm{Cmm}$. The culture medium was obtained YDC higher growth, while the lowest was observed in the middle and LPGA NBY, respectively. The maximum growth rate on YDC was with 1.71 division's day ${ }^{-1}$ in the cultures under continuous light and 1.0 divisions day ${ }^{-1}$ with photoperiod and 1.39 divisions day ${ }^{-1}$ in the cultures under continuous light at 25 psu (power supply unit). The cumulative growth rate was above three divisions/day for these same media and light conditions, while the other treatments were minor. Thessen et al. [26], mention that the optimal growth in different culture media depends on the species of bacteria because they found that Ralstonia had a maximum growth rate on PDA, while the maximum growth was about half Ralstonia KB (B King) and gender showed a growth Pectobacterium intermediate between the other two genera (Figure 1). Analyzing the highest cell concentrations at the end of the experiment in each of the means were significant differences $(\mathrm{P}<0.05)$ in the three culture media, it was observed that was higher on 555.000 \pm 137.000 YDC of cfu/mL with continuous light and $453.000 \pm 89.000 \mathrm{cfu} / \mathrm{mL}$ with photoperiod, and decreased significantly $(P<0.05)$ with LPGA medium (Figure 1$)$. The answer to the cell culture medium with respect to the variation of the components of the culture medium is different depending on the species of bacteria grown. In the present study, the decrease of cell concentration in the culture media used is consistent with Rosales

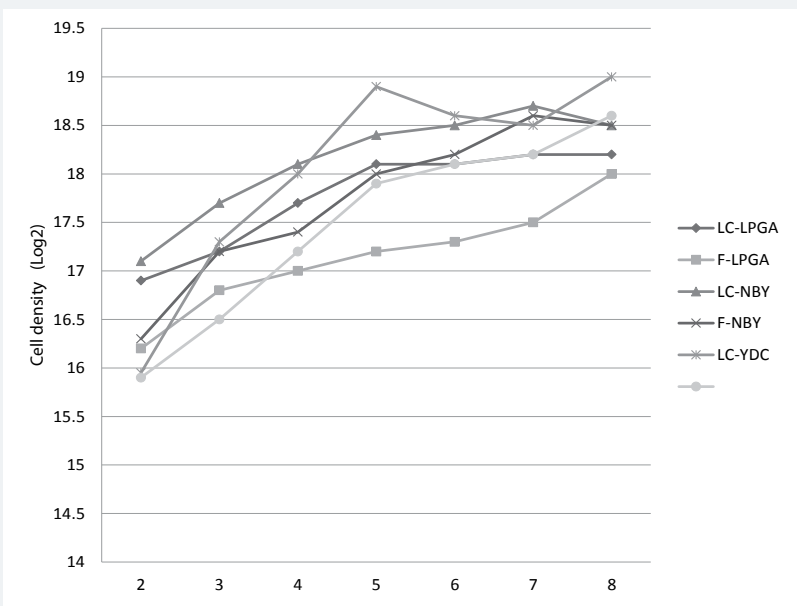

Figure 1: Cell growth curves of Clavibacter michiganensis subsp michiganensis $(\mathrm{Cmm})$ in different culture medi (YDC, LPGA and NBY) with continuous light (LC) and photoperiod (F). 
and Morales [27], who found that the highest cell density of $\mathrm{Cmm}$ strain $\mathrm{H}$ was in YDC. Meanwhile, Arroyo and Martinez [28], reported that Mycobacterium grown under controlled laboratory conditions decreased cell density means less enriched with salts. Lopez et al. [8] found that Osochrysis sp. shows a higher cell density at low concentrations of salts, however, Castro and Tavano [29], observed that the salts had no significant effect $(\mathrm{P}>0.05)$ on growth and maximum cell density of Chaetoceros wighamii. Changes in culture media with different nutrient (salt) affect the organisms in three ways: a) osmotic stress with direct impact on cellular water potential, b) ionic stress caused by the entry or loss of ions and c) change in the rate of ion selective membrane [25]. Besides affecting nutrients, light regime also plays an important role since it also affects the growth and biomass production of crops [30]. In this research the two lighting conditions showed no statistically significant effect on maximum cell concentration in the treatments, but the maximum growth rate $(\mathrm{P}<0.05)$ and the cumulative growth rate. The photoperiod with $12 \mathrm{~h}$ light: $12 \mathrm{~h}$ dark had slower growth, a finding consistent with Brown et al. [31], who reported that Ralstonia had a maximum growth rate of 1.9 with continuous illumination and a photoperiod with $12 \mathrm{~h}$ light: $12 \mathrm{~h}$ dark. On the other hand, Humphrey [32], found a slower growth of Agrobacterium when grown in the cycle of $12 \mathrm{~h}$ light: $12 \mathrm{~h}$ dark compared to cultures exposed to continuous illumination. The diatoms Chaetoceros and Phaeodacttylum didytum tricornutum showed a growth rate under continuous light of 0.6 and 1.7 respectively, and a photoperiod of 0.4 and 1.2 .

\section{Conclusions}

For the present investigation we conclude the variability to detect $\mathrm{Cmm}$ in seed of tomato and chili by Immunochromatography and ELISA techniques. With the serological techniques of immunochromatography, ELISA and biochemical and physiological tests, the effectiveness of a phytopathological diagnosis in a timely manner to identify bacteria is demonstrated. Therefore, it is recommended to consider the fusion of diagnostic techniques in the emission of a result. According to the evaluation of different culture media on the growth and cellular density of $\mathrm{Cmm}$, for purposes of isolation, detection and exponential growth of bacteria, continuous light conditions are continued by proposing the YDC medium for $\mathrm{Cmm}$.

\section{References}

1. SIAP. Secretaría de Agricultura, Ganadería, Desarrollo Rural, Pesca y Alimentación. Por Estado y Cultivo. Sistema Integral de Información Agroalimentaria y Pesquera. 2017. Ref.: https://goo.gl/Divcbp

2. CAADES. Cierre de ciclo de hortalizas. Confederación de Asociaciones Agrícolas del Estado de Sinaloa. 2017; 3: 10-13.

3. Messiaen CM. Enfermedades de las hortalizas. Mundi prensa. Primera ed. México. 2005; 575.

4. Nandi M, Macdonald J, Liu P, Weselowski B, Yuan ZC. Clavibacter michiganensis ssp. michiganensis: bacterial canker of tomato, molecular interactions and disease management. Mol Plant Pathol. Ref.: https://goo.gl/RPcCvm

5. Eichenlaub R, Gartemann KH. The Clavibacter michiganensis subspecies: Molecular investigation of Gram-positive bacterial plant pathogens. Annu Rev Phytopathol. 2011; 49: 445-464. Ref.: https://goo.gl/SUjKSH

6. Rueda PE. Cuando las enfermedades traspasan las fronteras: México un caso. Congreso Mundial de Trichoderma y Fitopatología. Costa Rica 19 mayo de 2008.

7. Rueda PE, Medina $D$, Alvarado $M$, García $O$, Tarazón $H$, et al. Detección y caracterización de Clavibacter michiganensis subsp. sepedonicus en papa en el estado de Sonora, México. Tropical and Subtropical Agroecosystems. 2009; 10: 13-20.

8. López EJA, Huerta-Aldaz N, EstradaDurán GC, Salgado MP, Re Vega E, et al. Effect of salinity on the growth of Isochrysis sp. under static culture conditions. Biotechnology. 2004; 3: 10-15. Ref.: https://goo.gl/tdesed

9. Rueda-Puente EO, Tarazón-Herrera MA, García-Hernández JL, Murillo-Amador B, Holguín-Peña RJ, et al. Production of antibodies for bacterial fruit blotch [Acidovorax avenae pv. citrulli (Schaad, Sowell, 
Goth, Colwell y Webb) Willems, Goor, Thielemans, Gillis, Kersters y De Ley] of watermelon (Citrullus vulgaris Schrad.) in the region Comarca Lagunera, Mexico. Revista Mexicana de Fitopatología. 2006; 24: 129-135. Ref.: https://goo.gl/8Fkn76

10. Borboa Flores J, Rueda Puente EO, Acedo Félix E, Ponce JF, Cruz M, et al. Detection of Clavibacter michiganensis subspecies michiganensis in tomato of the state of Sonora, Mexico. Revista Fitotecnia Mexicana. Bravo, Aldunate MyAP 1993. Monografías Hortícolas. CORFO. PUCCH. Santiago. 2009; 136. Ref.: https://goo.gl/G9voEr

11. SAS Institute. SAS/STAT user's guide, Version 6.12 SAS, Institute, Cary, NC, USA. 2001.

12. Osuna G, Rodríguez yF. Distrito de Desarrollo Rural Culiacán. ddr004@sin.sagarpa.gob.mx. carret. a Navolato km. 7.5 Bachigualato, Culiacán, Sinaloa. CP. 80140. SAGARPA-Culiacán. 2017; 120.

13. AGDIA. 2017. Ref.: https://goo.gl/n9pEZj

14. Davis MJ. Taxonomy of plant-pathogenic coryneform bacteria. Annual Review of Phytopathology. 1996; 24: 115-140. Ref.: https://goo.gl/VmmhPQ

15. Rodríguez MML. Manual para la Identificación de Bacterias Fitopatogenas, $2^{\text {nd }}$ Ed. Universidad Autónoma de Chapingo. 2001; 80-96.

16. Rodríguez RR, Rodríguez JMT. Medina SJA. Cultivo moderno del tomate. Segunda Reimpresión. Ed. Mundi-Prensa. Madrid, España. 2001; 15-19. Ref.: https://goo.gl/9Ai1sy

17. Schaad NW, Jones JB, Chun W. Laboratory Guide for Identification of Plant Pathogenic bacteria, APS Press, USA. 2001; 1-15.

18. Sharabani G, Manulis-Sasson S, Borenstein M, Shulhani R, Lofthouse M, et al. The significance of guttation in the secondary spread of Clavibacter michiganensis subsp. michiganensis in tomato greenhouses. Plant Pathol. 2013; 62: 578-586. Ref.: https://goo.gl/paVzpv

19. Sharabani G, Manulis-Sasson S, Chalupowicz L, Borenstein M, Shulhani R, et al. Temperature at the early stages of Clavibacter michiganensis subsp. michiganensis infection affects bacterial canker development and virulence gene expression. Plant Pathol. 2014; 63: 1119-1129. Ref.: https://goo.gl/en56ZH

20. Fatmi M, Schaad NW. Survival of Clavibacter michiganensis ssp. michiganensis in infected tomato stems under natural field conditions in California, Ohio and Morocco. Plant Pathol. 2002; 51: 149154. Ref.: https://goo.gl/LnfBAe

21. Lou LX, Walters BH, Liu XL, Li JQ. Quantification of variable cells of Clavibacter michiganensis subsp. michiganensis using a DNA binding dye and a rad-time PCR assay. Plant Pathol. 2007; 135: 1365-3059.

22. Borboa FJ. Detección e incidencia de Clavibacter michiganensis subespecie michiganensis en Lycopersicon esculentum Mill. en el estado de sonora, México y evaluación del efecto bactericida de aceites esenciales. Tesis de Posgrado. Universidad Autónoma de Baja California. Mexicali, Baja California, México. 2009; 80.

23. Thyr BD, Samuel MJ, Brown PG. New solanaceous host records for Corynebacterium michiganense. Plant Disease Reporter. 2003; 59: 595-598. Ref.: https://goo.gl/ny258v

24. Sen $\mathrm{Y}$, van der Wolf J, Visser RGF, van Heusden S. Bacterial canker of tomato: Current knowledge of detection, management, resistance, and interactions. Plant Dis. 2015; 99: 4-13. Ref.: https://goo.gl/qBm7Mm

25. Mansour MMF, Salama KHA. Cellular basis of salinity tolerance in plants. Environ Exp Bot. 2004; 52 113-122. Ref.: https://goo.gl/4xAzg5

26. Thessen AE, Dortchm Q, Parson ML. Effect of salinity of Pseudo-nitzschia species growth and distribution. J Phycol. 2005; 41: 21-29. Ref.: https://goo.gl/taFiw2

27. Rosales NO, Morales JyR. Influencia de la salinidad sobre crecimiento y composición bioquímica de la Clavibacter michiganensis ssp. michiganensis. Ciencias Marinas. 2005; 31: 349-355.

28. Arroyo-Pacheco LE, Martínez-Baldenebro F. Producción de biomasa y composición química de dos especies de microalgas a diferentes salinidades. Tesis de Licenciatura. Universidad de Sonora. Hermosillo, Sonora, México. 1994; 78.

29. Castro AS, Tavano G. Growth and biochemical composition of the diatome Chaetocerus under different temperature, salinity and dioxide carbon levels. Aquaculture. 2005; 246: 405-412. Ref.: https://goo.gl/EDwUVP 
30. Tzovenis I, De Pauw N, Sorgeloos P. Optimization of T-ISO biomass production rich in essential fatty acids. Aquaculture. 2005; 203-222.

31. Brown MR, Dunstan GA, Norwood SJ. Effects of harvest stage on the biochemical composition of the diatome. Journal of Phycology. 1996; 32: 64-73. Ref.: https://goo.gl/eMVtN1

32. Humprey GF. Photosynthetic characteristics under constant illumination and light dark regimes. Journal of Experimental Marine Biology and Ecology. 1979; 40: 63-70. Ref.: https://goo.gl/nEE4nL

33. Gitaitsis RD, Sasser MJ, Beaver RW, McInnes TB, Stall RE. Pectolytic Xanthomonads in mixed infections with Pseudomonas syringae pv. syringae, $P$. syringae pv. tomato, and Xanthomonas campestris pv. vesicatoria in tomato and pepper transplants. Phytopathology. 1987; 77: 6II-615. Ref.: https://goo.gl/VVfN1E

34. López EJA, Huerta-Aldaz N, EstradaDurán GC, Salgado MP, Re Vega E, et al. Effect of salinity on the growth of Isochrysis sp. under static culture conditions. Biotechnology. 2004; 3: 10-15. Ref.: https://goo.gl/tdesed

35. Velázquez-Alcaraz TJ, Partida-Ruvalcaba L, Acosta-Villegas B, Ayala-Tafoya F. Producción de plantas de tomate y chile aplicando paclobutrazol al follaje. Universidad y Ciencia. 2008; 24: 21-28. Ref.: https://goo.gl/SmQAMf 